\title{
Improving Students' Writing Skill in Writing Narrative Text Through Picture And Picture Method
}

\author{
M. Hilmy Hidayatullah \\ English Department, Social and Humanity Science Faculty, University of Ibrahimy \\ Email Correspondence : hilmizuhil@gmail.com
}

A R T I C LE INF O

\section{Keywords:}

Improve

Writing Skill

Narrative Text

Picture

\section{Article History:}

Received : 13 December 2021

Accepted : 11 January 2022

Published : 14 February 2022

\section{A B S T R A C T}

One of the important materials in reading skills is narrative text. The narrative text is taught since the 8th grade of Junior High School and is a mandatory material until it is included in the National Examination (UN) grid, college entrance exams, and TOEFL. The narrative text is a type of English text that aims to tell a story that has a series of connected chronological events. It is the main part of English text taught in Junior High School. Unfortunately, researchers still found many students who did not master narrative texts, especially in grade 8 of SMP Ibrahimy 1 Sukorejo. The picture and picture model is one of the learning models that can improve students' writing skills in narrative texts. The Picture and Picture model has the same principle and way of working as the method of learning to compose pictures. Students are equally asked to arrange pictures that have been prepared sequentially and systematically. Systematic and sequential according to the reasoning and logical strength of students. This research used the classroom action research method and was conducted in 2 cycles through four stages, namely planning, implementation, observation, and reflection. Data collection techniques used were observation, questionnaires, and tests. The finding of this research showed that picture and picture models could improve students' writing skills in writing narrative text. 


\section{Introduction}

There are 4 skills in English that must be mastered by students, they are listening, speaking, reading and writing. In the 2013 curriculum, Junior High School students are emphasized to master reading and writing skills, without denying speaking skills. By mastering reading and writing skills, students are expected to form simple sentences.

One of the important materials in reading skill is narrative text. This narrative text is taught since the 8th grade Of Junior High School, and is a mandatory material until it is included in the National Examination grid, college entrance exams and TOEFL. But in reality, researchers still find many students who do not master narrative texts, especially in grade 8 of SMP Ibrahimy 1 Sukorejo. This is evident from the small score obtained by the 8th grade students of SMP Ibrahimy 1 Sukorejo. Most of them still do not memorize vocabulary and do not master the structure of English. As a result, they cannot arrange sentences and paragraphs well. This causes students difficulty in capturing the meaning of words and understanding the generic structure in narrative texts.

Narrative Text is a type of English text that aims to tell a story that has a series of connected chronological events. There are many types of narrative text, including fairy stories, mysteries, science fiction, romances, horror stories, adventure stories, fables, myths and legends, historical narratives, ballads, slice of life, personal experience, etc. Meanwhile, what the researchers focused on in this study were fables because of the availability of references and learning media, as well as because the fable text was easy to understand by students.

The learning purpose of the ability to read English narrative texts in the form of fables determined based on basic competencies in the content standards of the 2013 curriculum is that students can identify social functions, moral values, detailed information, and direct and indirect sentences. As well as explaining the main ideas and linguistic elements of narrative texts in the form of short and simple fables to get entertainment, entertain and teach noble values through stories with animal characters, using expressions with coherent text structures with linguistic elements that are correct and in context, honestly, discipline, self-confidence, responsibility, care, cooperation and love of peace.

From these problems, appropriate techniques and methods are needed to help and motivate students in understanding narrative texts. Picture and Picture is a very precise method to solve the problem. Active activities of students compiling pictures, and supported by colorful pictures make learning more fun. Therefore, the researcher took the Picture and Picture approach to be applied in teaching narrative texts. Teachers can also apply this method in the learning process. Picture and Picture can be used to visualize students' ideas and then write them in good and correct paragraphs.

According to Suprijono (2009), as quoted by Miftahul Huda (2013), Picture and Picture is a learning strategy that uses pictures as a medium of learning. This strategy is similar to the Example non-Example strategy, where the pictures given to students must be paired or ordered logically. These pictures become the main tool in learning. After students arrange the pictures in the correct order, the students then write down the stories in each of the pictures. The Picture and Picture model has the same principle and way of working as the method of learning to compose pictures. Students are equally asked to arrange pictures that have been prepared sequentially and systematically. Systematic and sequential according to the reasoning and logical strength of children (students). The difference is, in the Picture and Picture Model, students are asked to sort the pictures provided by the teacher one by one in front of the class (Muliawan: 2016). 
Because Picture and Picture is an active learning method, where students sequence pictures and discuss the contents of the story with groups, the researchers hope that by using the Picture and Picture model in learning to write English narrative texts, grade VIII students, especially grade VIII B students in SMP Ibrahimy 1 will pay attention to the teacher's explanations, feel happy to follow the lesson, be active in discussions, pay attention to friends who are presenting so that students can write narrative texts themselves, understand social functions, linguistic elements and capture the meaning of narrative text words.

The aims of this study are (a) to find out whether the use of the Picture and Picture model can improve learning activities to write English narrative texts for class VIII B students of SMP Ibrahimy 1 Sukorejo Banyuputih Situbondo; (b) to find out whether the use of the Picture and Picture model can improve the students's writing skill to write English narrative texts of class VIII B SMP Ibrahimy 1 Sukorejo Banyuputih Situbondo.

\section{Methods}

This classroom action research was conducted at the Ibrahimy 1 Sukorejo Junior High School which is located on KH. Syamsul Arifin Street, Sukorejo, Banyuputih, Situbondo. The writer chose this place because students in class VIII B Ibrahimy had difficulty in writing narrative texts, so this research is very suitable to be studied in that place. The research was implemented in the even semester of the 2020/2021, for 3 months, from January to March 2021. This time was used for initial reflection, proposal writing, implementation of classroom action research activities consisting of two cycles and report writing.

The research subjects were students of class VIII B SMP Ibrahimy 1 Sukorejo. Class VIII B consists of 35 students. Most of these students had middle to lower economic backgrounds. The author felt challenged to conduct the research in this class because the activities and academic abilities were very lacking. In Chapter I, it is explained that the ability to compose narrative texts for class VIII B is always low. This is evidenced by the average result of the initial test only reaching 31.59 and no one reaching the minimum completeness criteria (KKM), which is 70 . This study used a classroom research design developed by Kemmis and Mc Taggart.

In this study, the researcher collaborated with an English teacher. The collaborator acted as an observer when the researcher carried out the action, namely carrying out the learning process using the Picture and Picture model. This research was carried out in 2 cycles consisting of 4 stages, namely 1) planning, 2) implementation, 3) observation, and 4) reflection. Before carrying out these stages, the researcher first did an initial reflection to identify the problem.

Before starting the research, the researcher first did an initial reflection based on observations in the classroom. The researcher also gave an initial test to the research subject, From the initial reflection, the researcher was able to identify the research problem, that was the low activity and learning outcomes of students' writing skill to write English narrative texts.

Cycle 1 consists of stages (1) Planning. In this stage the researchers did the following things, (a) Making learning tools, (b) Preparing learning materials, (c) Preparing learning media and tools, (d) Preparing research instruments, (e) Preparing learning models, (f) Develop indicators of success. (2) Implementation/action; At this stage the researcher took action by using Picture and Picture in the ability to write English narrative texts. This action was carried out at the first and second meetings. (3) Observation. Observation activities are observations made by researchers or other observers. In this case, the researcher asked colleagues to help become observers during the learning activities. This was intended so that the observation process run optimally. (4) Reflection. After doing the action and observation, the researcher did a reflection together with the students 
by doing an assessment on the narrative text material. This was intended to measure the success of achieving learning targets. From this reflection, it would be known whether there was a significant improvement. If yes, then the researcher no longer needed to do the second cycle. but if the data obtained in cycle 1 showed that there was no change in increasing learning outcomes, then the researcher needed to continue in the second cycle.

Cycle 2: Based on the results of reflection in cycle 1, if there was no increase in expected learning outcomes, the second cycle was carried out with the following steps. 1. Planning. In this stage, the researcher did the following: (a) problem identification, (b) action plan. The planned action was through pictures and pictures as an effort to improve learning outcomes. 2 . Implementation includes: (a) preparing the next lesson plan. (b) evaluate student learning outcomes through cycle tests. 3. Observation. Observations must really have to re-data the results of observations in cycle 1. 4. Reflection. After conducting research in cycles 1 and 2, an analysis of accurate data was obtained, from the results of the research, it could be carried out to reflect whether the results of research using the picture and picture method can be applied in the learning activity.

There were 2 types of data in this study, qualitative data and quantitative data. For data collection, researchers used 3 techniques, (a) Observation, (b) Questionnaire, and (c) Test. The observation technique was carried out for collecting qualitative data relating to the learning process. The questionnaire technique was also implemented to obtain qualitative data about the learning process. The instrument used is a questionnaire sheet. While the test technique was used to obtain quantitative data relating to learning outcomes.

\section{Result and Discussion}

This research was carried out in the even semester of the 2020/2021 at Junior High School of Ibrahimy 1 Sukorejo for 3 months including preparation and reporting, starting from January to March 2021 which was divided into 2 cycles. Each cycle consists of planning, implementation/action, observation and reflection. The research subjects were students of class VIII B SMP Ibrahimy 1 whose activity and learning outcomes in English writing skills were very low. This research was monitored directly by supervisor $1 \mathrm{Mr}$. Abd. Majid, S.Ag. and supervisor 2 Mr. Ibnu Ruslan Nurus Zaman, S. Hum. as an English teacher.

At the pre-cycle meeting, the researcher tried to carry out classical learning without the Picture and Picture method. In class, researchers found it difficult because students did not pay attention to the teacher, talked to their friends and the learning outcomes were not satisfactory. This was because the learning process was not interesting and did not stimulate students to learn, so students felt bored in the class. The data in the following table:

\subsection{Student activity observation research}

Table 1. Students Activity

\begin{tabular}{llcc}
\hline No. & \multicolumn{1}{c}{ Observation } & Cycle 1 & Cycle 2 \\
\hline 1. & Do the students pay attention to the teacher's explanation? & $43 \%$ & $100 \%$ \\
2. & Do students pay attention to the students' discussion? & $49 \%$ & $91 \%$ \\
3. & Are students actively asking questions? & $37 \%$ & $74 \%$ \\
4. & Are students actively discussing? & $46 \%$ & $100 \%$ \\
& Average score & $44 \%$ & $91 \%$ \\
\hline
\end{tabular}


From the results of the observation test, cycle 1 can be concluded that on average only $43 \%$ of students pay attention to the teacher's explanation, inversely, that is $100 \%$ of students pay attention to the teacher's explanation. This proves that the picture and picture method is very effective in focusing students' attention on learning. In addition, only $49 \%$ paid attention to a friend's explanation in cycle 1 , and increased to $91 \%$ in cycle 2 . Meanwhile, $37 \%$ of students actively asked questions in cycle 1 , and in cycle 2 the number increased to $74 \%$ of students who actively asked. The students who are actively discussing are $46 \%$ in cycle 1 , and in cycle 2 , all students $(100 \%)$ are actively discussing.

\subsection{Questionnaire results}

Table 2. Questionnaire

\begin{tabular}{clcc}
\hline No. & \multicolumn{1}{c}{ Questions of Questionnaire } & Cycle 1 & Cycle 2 \\
\hline $1 . \quad \begin{array}{l}\text { Do you like Picture and Picture learning model? } \\
\text { Can Picture and Picture make you better }\end{array}$ & $100 \%$ & $100 \%$ \\
2. $\quad \begin{array}{l}\text { understand narrative text / can increase your } \\
\text { score? }\end{array}$ & $100 \%$ & $100 \%$ \\
$\quad \begin{array}{l}\text { Can Picture and Picture improve your learning } \\
\text { activities? }\end{array}$ & $97 \%$ & $100 \%$ \\
\hline
\end{tabular}

From the results of student questionnaires, it can be concluded that there is an increase in students' activity. This is because students already feel that the picture and picture method can improve student learning outcomes. Therefore, it can be seen in the table that the acquisition of the questionnaire results from cycle 1 was quite high (97\%), and got a perfect score in cycle 2 (100\%).

\subsection{Test Result}

Table 3. Test Result

\begin{tabular}{|c|c|c|c|c|c|}
\hline \multirow{2}{*}{ No } & \multirow{2}{*}{ Name } & \multicolumn{2}{|r|}{ Cycle 1} & \multicolumn{2}{|r|}{ Siklus 2} \\
\hline & & Result & Complete/ incomplete & Result & Complete/ incomplete \\
\hline 1 & Achmad Mostofa & 70 & Complete & 80 & Complete \\
\hline 2 & Achmad Sopyan & 75 & Complete & 80 & Complete \\
\hline 3 & Ahmad Basofi & 60 & Incomplete & 70 & Complete \\
\hline 4 & Ali Ghufron & 55 & Incomplete & 65 & Incomplete \\
\hline 5 & Aliffia Gilang M. & 60 & Incomplete & 70 & Complete \\
\hline 6 & Amir Mahmud & 80 & Complete & 85 & Complete \\
\hline 7 & Andi Herman & 60 & Incomplete & 70 & Complete \\
\hline 8 & Aris Wiranto & 55 & Incomplete & 60 & Incomplete \\
\hline 9 & Daneal Hasan P & 65 & Incomplete & 70 & Complete \\
\hline 10 & Divani Aula Risbi & 85 & Complete & 90 & Complete \\
\hline 11 & Eep Shahibul & 70 & Complete & 75 & Complete \\
\hline 12 & Faiqur Rahman & 50 & Incomplete & 55 & Incomplete \\
\hline 13 & Fiqhi Nur Hidayat & 55 & Incomplete & 70 & Complete \\
\hline 14 & Gilang Fahmi & 60 & Incomplete & 70 & Complete \\
\hline 15 & Gildan Alviano & 60 & Incomplete & 75 & Complete \\
\hline
\end{tabular}




\begin{tabular}{llcccc}
\hline No & \multicolumn{1}{c}{ Name } & Result & $\begin{array}{c}\text { Cycle 1 } \\
\text { Complete/ incomplete }\end{array}$ & Result & $\begin{array}{c}\text { Siklus 2 } \\
\text { Complete/ incomplete }\end{array}$ \\
\hline 16 & Ilham Wildan & 75 & Complete & 80 & Complete \\
17 & Jofan Herbiyanto & 50 & Incomplete & 65 & Incomplete \\
18 & Kadek Akbar S. & 80 & Complete & 85 & Complete \\
19 & Kelik Tri Rahmadi & 85 & Complete & 90 & Complete \\
20 & Malikul Irfan & 60 & Incomplete & 70 & Complete \\
21 & Miftahul Anas & 70 & Complete & 75 & Complete \\
22 & Moh. Fadhail & 70 & Complete & 80 & Complete \\
23 & Moh. Febri & 75 & Complete & 80 & Complete \\
24 & Moh. Thoriq N & 60 & Incomplete & 65 & Incomplete \\
25 & M. Ainul Baihaki & 65 & Incomplete & 70 & Complete \\
26 & M. Agung S. & 60 & Incomplete & 70 & Complete \\
27 & M. Ali Muzaki & 60 & Incomplete & 70 & Complete \\
28 & M. Azam Abdani & 85 & Complete & 85 & Complete \\
29 & Roihan Musyahal & 70 & Complete & 80 & Complete \\
30 & Salman Alfarizi & 75 & Complete & 80 & Complete \\
31 & Seftian Adi & 55 & Incomplete & 65 & Incomplete \\
32 & Septian Dwi C & 50 & Incomplete & 70 & Complete \\
33 & Sobri Wazil & 80 & Complete & 85 & Complete \\
34 & Taufik Hidayat & 60 & Incomplete & 70 & Complete \\
35 & Ubai Dillah & 65 & Incomplete & 75 & Complete \\
& Average score & & 66 & & $\mathbf{7 4}$ \\
\hline
\end{tabular}

From this table, it can be concluded that there was a significant increase between cycle 1 and cycle 2 . In cycle 1 , the average student got a completeness score of 66 and had not passed because the passing grade was 70, while in cycle 2 he received a completeness score of 74 or passed. of passing grades. Because all the indicators of success that have been set can be achieved in cycle 2 , the study was stopped.

\section{Conclusion}

Based on the results of observations made by collaborators, the percentage of learning implementation at the end of cycles 1 and 2 reached 100\%. There was an increase in the percentage of student learning activities in learning activity and learning outcome. Data about the learning activities of class VIII-B students at SMP Ibrahimy 1 Sukorejo Situbondo obtained by observation techniques in cycle 1 and cycle 2, showed that from the activities students payed attention to teacher explanations, payed attention to friends' presentations, students actively asked or answered questions, and discussed in a group, the average percentage of these activities was $44 \%$, while in cycle 2 it is $91 \%$. From the results of the questionnaire, there was an increase of $3 \%$. This was because students already felt helped by the picture and picture method starting from cycle 1 . While the significant results were the test results. The average student got a score of 66 , or did not pass the passing grade, 70 , but in cycle 2 the average student had gotten a score of 74 or passed the passing grade.

The data obtained were both with observation, questionnaire, and test techniques in cycles 1 and 2, after being analyzed at the end of cycle 2, it turned out to be able to achieve all the 
indicators of success that had been determined. So researchers could draw conclusions from this study as follows:

a. The researcher carried out all processes of learning the ability to write English narrative texts for class VIII-B students at SMP Ibrahimy 1 Sukorejo Situbondo by using Picture and Picture in accordance with the lesson plans that were compiled before.

b. The use of the Picture and Picture model could improve the learning activities of writing narrative texts in English for grade VIII-B students at SMP Ibrahimy 1 Sukorejo Situbondo. This happened because learning with the Picture and Picture model is centered on students, not on the teacher.

The use of the Picture and Picture model could improve learning outcomes in the students' writing skill in English narrative texts for grade VIII-B students at SMP Ibrahimy 1 Sukorejo Situbondo. In Picture and Picture model, the students were required to arrange scrambled pictures and sort them in the correct order, and matched their vocabulary. This could make students better understand narrative texts so that student learning outcomes could increase.

\section{References}

Ainurrahman. (2009). Belajar dan Pembelajaran. Bandung: Alfabeta.

Departemen Pendidikan Nasional. 2007. Kamus Besar Bahasa Indonesia. Jakarta: Balai Pustaka. Dimyati. (2002). Belajar dan Pembelajaran. Jakarta: Adi Mahasatya. FKIP UT. (2016). Panduan Karil FKIP. Jakarta: Universitas Terbuka.

Gunadi I.K. (2012). Pengaruh Penerapan Model Pembelajaran Kooperatif Learning dengan Tutor Sebaya Berbantuan Picture and picture Terhadap Hasil Belajar TIK Siswa Kelas VII Semester Ganjil SMP 1 Sukasada Tahun Ajaran 2011/2012. Kumpulan Artikel Mahasiswa (KARMAPATI) 3(1):376-387. Denpasar, Bali : Jurusan Pendidikan Teknik Informatika Fakultas Teknik dan Kejuruan Universitas Pendidikan Ganesa.

Guza, Afnil. 2008. Standar Nasional Pendidikan. Jakarta: Asa Mandiri.

Hamdani. (2011). Strategi Belajar Mengajar. Bandung: CV Pustaka Setia.

Huda, Miftahul. (2014). Model-model Pengajaran dan Pembelajaran. Jogjakarta: Pustaka Belajar. KBI (Admin). (2015). Narrative Text: Pengertian, Tujuan, Jenis, Generic Structure, dan Contoh Terlengkap. (http://www.kuliahbahasainggris.com/narrative-text-pengertian-tujuanjenis-generic-structure-dan-contoh/)

Muliawan, Jasa Ungguh. (2016). 45 Model Pembelajaran Spektakuler Buku pegangan Teknis Pembelajaran di Sekolah. Jogjakarta: Ar-Ruz Media.

Partanto, Pius A, dkk. (2001). Kamus Ilmiah Populer. Surabaya: Arloka. 